This Supplemental Material accompanies Lund Snee, J.-E., and Miller, E.L., 2021, Magmatism, migrating topography, and the transition from Sevier shortening to Basin and Range extension, western United States, in Craddock, J.P., Malone, D.H., Foreman, B.Z., and Konstantinou, A., eds., Tectonic Evolution of the SevierLaramide Hinterland, Thrust Belt, and Foreland, and Postorogenic Slab Rollback (180-20 Ma): Geological Society of America Special Paper 555, https://doi.org/10.1130/2021.2555(13).

\title{
Magmatism, migrating topography, and the onset of faulting in the northern Basin and Range province, western USA
}

Jens-Erik Lund Snee ${ }^{1}$ and Elizabeth L. Miller ${ }^{2}$

${ }^{1}$ U.S. Geological Survey Geosciences and Environmental Change Science Center, P.O. Box 25046, MS 980, Denver, CO 80225

${ }^{2}$ Stanford University Department of Geological Sciences, 450 Serra Mall Bld. 320, Room 118, Stanford, CA 94305

\section{Contents of this GSA Supplemental Material}

1. Introduction

2. Text S1 to S4

3. Figures $\mathrm{S} 1$ to $\mathrm{S} 3$

4. References

5. Tables S1 to S3 (separate file) 


\section{INTRODUCTION}

This GSA Supplemental Material contains appendices and figures that support the text (below) as well as supplementary data tables (separate file). The first two appendices below present the detailed methods for obtaining new U-Pb detrital zircon ages (Text S1) and for assigning (maximum) depositional age constraints to sedimentary rocks in the Elko area of northeast Nevada (Text S2). Text S3 presents the results of $\mathrm{U}-\mathrm{Pb}$ detrital zircon analysis and Text S4 specifically details the new age constraints throughout the stratigraphic succession. Figures $\mathbf{S 1}$ and $\mathbf{S 2}$ respectively provide probability density plots and weighted mean age plots for each detrital zircon age sample. Finally, Figure S3 provides references for the ages of Great Basin paleodrainages, to support Figure 2 of the main body. References for this Supplemental Material are provided at the end. Any use of trade, firm, or product names is for descriptive purposes only and does not imply endorsement by the U.S. Government. 


\section{TEXT S1. METHODS FOR U-PB DETRITAL ZIRCON GEOCHRONOLOGIC}

\section{ANALYSES}

We sampled fine-grained sandstones for U-Pb detrital zircon analysis. We sought fresh, unexposed samples, and we removed weathering rinds with a rock hammer or shovel. Sampling localities, rock types, and other details are given in Table S1 and the locations are shown in Fig. 4. We blew dust off sampled rocks in the field and then again using compressed air in the laboratory in order to reduce the potential for contamination. Rock crushing, mineral separation, mount-making, geochronological analysis, and data reduction techniques closely followed those outlined by Dumitru et al. (2016) in their Data Repository.

We crushed rock samples and made zircon separates at Stanford University using standard procedures that included fracturing with a steel hammer followed by dust removal with compressed air, rock crushing, rock grinding, and concentration of denser grains using a modified Gemeni Table water-aided shaking apparatus. For the first of two sets of samples (15JLS002, 15JLS004, 15JLS015, 15JLS017, 15JLS027A, 15JLS029, 15JLS036B, and 15JLS037), which were separated in 2016, we employed a Frantz magnetic separator with $10^{\circ}$ side slope and final (maximum) power setting of 2.3A to progressively remove magnetic grains. Dumitru et al. (2016) recommended a final power setting of 1.2A, so our higher setting may have removed some zircon grains containing inclusions or mantled by volcanic material, which could have resulted in lower yields of younger, primary volcanic grains (Naeser and Naeser, 1984) when these samples were analyzed at the University of California Santa Cruz. If this occurred, it would not weaken the integrity of maximum depositional ages (MDAs), but it could produce older MDAs for some samples, rendering the age constraints more conservative. Hence, for three samples initially separated in this manner in which we observed zircon in the magnetic fractions (15JLS029, 15JLS036B, and 15JLS037), we later (2018) combined all nonmagnetic fractions that were yielded from power settings of 1.2A and greater and extracted zircons again from these samples. These additional zircon separates, together with one additional sample not previously separated (15JLS041), were analyzed at the University of Arizona LaserChron Center.

Nonmagnetic mineral separates were fractionated by density using $3.32 \mathrm{~g} / \mathrm{cm}^{3}$ methylene iodide according to methods outlined by Dumitru and Stockli (1998). The resulting heavy fraction containing zircon was rinsed multiple times using deionized water. Zircon crystals were 
placed on an epoxy mount, photographed with the aid of an optical microscope, and then analyzed. For the first group of samples, separated in 2016, analyses were conducted on an Element XR high-resolution magnetic-sector inductively coupled plasma mass spectrometer (ICP-MS) outfitted with a single collector and housed at the University of California, Santa Cruz, Institute of Marine Sciences. A total of 1000 analyses were conducted on sample grains. Our analyses were conducted using the 2015 instrument configuration and workflow described by Dumitru et al. (2016), but we selected slightly different parameters for laser ablation:

- Laser fluence: $4.0 \mathrm{~J} / \mathrm{cm}^{2}$

- Repetition rate: $8 / \mathrm{s}$

- Shot count: 160 (20 s total duration)

- Spot size: $20 \mu \mathrm{m}$.

For these analyses, we employed Temora 2 zircon (416.78 \pm 0.33 Ma isotope dilution-thermal ionization mass spectrometry weighted mean age by Black et al., 2004) as the primary age reference material (standard). A total of 210 grains of Temora 2 were analyzed, one after every fifth unknown age analysis, with additional Temora 2 analyses at the start and end of the session. We employed FC-5Z zircon (1099 $\pm 0.6 \mathrm{Ma}$; see Paces and Miller, 1993) as a secondary age reference material. One hundred eight analyses were made of FC-5Z. Mount Dromedary ("DROM") zircon (98.8 $\pm 0.6 \mathrm{Ma}$; White and Ireland, 2012) was employed as a tertiary age reference material and analyzed 50 times during the session. The zircon concentration reference material MADDER was used to estimate $\mathrm{U}, \mathrm{Th}$, and $\mathrm{Pb}$ abundances. MADDER was analyzed several times at the start of the session, and then once per approximately 50 other analyses.

Data reduction was conducted with the Iolite v.2.5 add-in to IGOR Pro v.6.3 (Paton et al., 2011) using the "U_Pb_Geochronology3" data reduction scheme. Baseline subtraction was applied using the "StepForward" spline. Baseline integrations were trimmed manually to exclude zones where ${ }^{202} \mathrm{Hg}$ and ${ }^{204} \mathrm{~Pb}$ signal diverged from the mean of the baseline by 3 standard deviations or more. A correction for downhole fractionation was applied using Temora 2 as the reference material. Integration windows for the all reference materials were trimmed at the start and end in order to maximize the quality of fit of a double exponential downhole correction curve. We removed spikes of ${ }^{204} \mathrm{~Pb}$ detected in Temora 2 analyses by manually trimming individual integrations away from the end. Finally, we interpolated signal between Temora 2 primary reference materials using "Spline_Smooth_Med5," which yielded the following 
statistics for final, downhole-corrected $206 \mathrm{~Pb} / 238 \mathrm{U}$ ages of the reference materials: MSWD = 0.92 for primary reference material Temora $2, \mathrm{MSWD}=1.1$ for secondary reference material FC-5Z, and MSWD = 1.3 for tertiary reference material Mount Dromedary ("DROM"). Integrations of unknown analyses were deleted or trimmed away from the end according to criteria established by Dumitru et al. (2016). We employ their comment codes in our Table S2 as explanation for modifications to integration windows. We also add the comment "moved" in cases where the integration window was simply shifted due to a mismatch with the signal time series.

The single-collector ICP-MS at the UCSC Marine Sciences is unable to resolve ${ }^{204} \mathrm{~Pb}$ due to isobaric interferences with ${ }^{204} \mathrm{Hg}$, preventing the use of a ${ }^{204} \mathrm{~Pb}$-based common $\mathrm{Pb}$ correction. Instead, we applied a ${ }^{207} \mathrm{~Pb}$-based correction to ${ }^{206} \mathrm{~Pb} /{ }^{238} \mathrm{U}$ ages $\leq 800 \mathrm{Ma}$ using Isoplot v.3.75 (Ludwig, 2008). Although the 207-correction can yield erroneously young ages in cases where crystals have experienced significant Pb loss (Andersen et al., 2019), this correction is viable for younger grains (those $\leq \sim 800 \mathrm{Ma}$ ), and especially for those younger than $\sim 100 \mathrm{Ma}$. This is because the common $\mathrm{Pb}$ composition is estimated by subtracting the radiogenic ${ }^{207} \mathrm{~Pb}$ from the total. Since ${ }^{238} \mathrm{U}$ is much $(137 \times)$ more abundant than ${ }^{235} \mathrm{U},{ }^{206} \mathrm{~Pb}$ (from ${ }^{238} \mathrm{U}$ ) is highly radiogenic, unlike ${ }^{207} \mathrm{~Pb}$ (from ${ }^{235} \mathrm{U}$ ). Hence, at relatively young ages, subtracting out the radiogenic ${ }^{207} \mathrm{~Pb}$ is more reliable because it represents a low proportion and will therefore result in a smaller potential correction. Because the youngest coherent group of ages for our samples (used to determine MDAs) is exclusively less than ca. $31 \mathrm{Ma}$, this method is especially viable for our study. Moreover, we applied a number of criteria, described below, to ensure reliable ages in general and to limit the potential that the correction could yield erroneously young ages.

In cases where the ${ }^{206} \mathrm{~Pb} /{ }^{238} \mathrm{U}$ age exceeded $1000 \mathrm{Ma}$, we took uncorrected ${ }^{207} \mathrm{~Pb} /{ }^{206} \mathrm{~Pb}$ ages to represent the best age. We applied the following filtering criteria to omit analyses that exhibited discordance, reverse discordance, or potentially high common $\mathrm{Pb}$ :

- ${ }^{206} \mathrm{~Pb} /{ }^{238} \mathrm{U}$ ages $>800 \mathrm{Ma}$ and discordance $>30 \%$ relative to ${ }^{207} \mathrm{~Pb} /{ }^{206} \mathrm{~Pb}$ ages

- ${ }^{206} \mathrm{~Pb} /{ }^{238} \mathrm{U}$ ages $>800 \mathrm{Ma}$ and discordance $<-7 \%$ (reverse discordance) relative to ${ }^{207} \mathrm{~Pb} /{ }^{206} \mathrm{~Pb}$ ages

- ${ }^{206} \mathrm{~Pb} /{ }^{238} \mathrm{U}$ ages $<1000 \mathrm{Ma}$ and ${ }^{207} \mathrm{~Pb}$-based common $\mathrm{Pb}$ correction to the ${ }^{206} \mathrm{~Pb} /{ }^{238} \mathrm{U}$ ages $>10 \%$ relative to uncorrected ${ }^{206} \mathrm{~Pb} /{ }^{238} \mathrm{U}$ ages

- ${ }^{206} \mathrm{~Pb} /{ }^{238} \mathrm{U}$ ages $\geq 1000 \mathrm{Ma}$ and ${ }^{206} \mathrm{~Pb} /{ }^{204} \mathrm{~Pb}<250$ 
- Extremely high errors $(2 \sigma)$ that are greater than the corresponding "best age." There is no indication of systematic $\mathrm{Pb}$ loss among the grains to which the 207-correction was applied. The 207-correction was usually exceedingly small, as is documented in Table S2; the vast majority of grains were corrected by $<<1 \mathrm{Ma}(\leq 1 \%)$.

For the second group of samples, separated in 2018, analyses were conducted on a $\mathrm{Nu}$ Plasma multi-collector LA-ICP-MS attached to a Photon Machines Analyte G2 excimer laser at the University of Arizona LaserChron Center. Reference materials were supplied by the LaserChron Center and included their Sri Lanka (SL) zircon as a primary reference material and R33 (419.26 $\pm 0.39 \mathrm{Ma}$; Black et al., 2004) as a secondary reference material. Analytical procedures are outlined by Gehrels et al. (2006, 2008), and they include an automatic ${ }^{204} \mathrm{~Pb}$ based common $\mathrm{Pb}$ correction. The same filtering criteria were applied to this second group of samples. However, because the Nu Plasma multi-collector instrument is able to resolve ${ }^{204} \mathrm{~Pb}$, we also omitted analyses with ${ }^{204} \mathrm{~Pb}>700 \mathrm{cps}$.

Plots of weighted mean depositional or maximum depositional ages (Fig. S2) and age probability distributions (Fig. S1) were generated using Isoplot v.3.75. U-Pb ages by analysis and isotopic data used to calculate these ages are presented in Table S2. All weighted mean errors except for that of sample 15JLS029 are calculated according to the $95 \%$ confidence error of the weighted average. In the case of 15JLS029, only two grains are present in the youngest coherent group of ages, so we estimate the weighted mean errors using only the $2 \sigma$ internal error (error propagated from only the assigned data-point errors), not multiplied by the square root of the mean square weighted deviation, MSWD). Only the young $(\leq 70 \mathrm{Ma})$ analyses are shown in Fig. S2. Preferred MDAs (in green) are typically based on the weighted mean of the youngest coherent group of analyses. Fig. S2 also presents weighted mean ages (in black) with sufficient additional grains included to achieve MSWD $\sim$, although these are not our preferred ages. 


\section{TEXT S2. METHODS FOR ASSIGNING (MAXIMUM) DEPOSITIONAL AGES}

As illustrated in Fig. 5, three techniques were applied to determine depositional age constraints for the strata sampled for stable isotope values, depending on the types of rocks and available age data. The youngest isotopically dated mineral population within a detrital sample provides a maximum depositional age (MDA). Second, fossil ages (from previous studies) provide age brackets for all or part of a stratigraphic unit. Third, isotopic dating or tephra correlation conducted on volcanic minerals within air- or water-lain tuffs can, in some cases, provide absolute depositional ages. Although it is possible that such tuffs experienced some reworking by fluvial or lacustrine processes, their eruption ages are likely close to the time of deposition (probably $<<1 \mathrm{Ma}$ ). This is supported by the large number of temporally distinct Cenozoic tuffs preserved in basins across the northern Basin and Range Province, often with short gaps between subsequent eruptions, all of which typically provide tight temporal constraints on depositional ages (Wallace et al., 2008). In particular, Neogene silicic tuffs erupted from the Snake River Plain (Fig. 1) provide excellent and high-resolution age control for basin-and-range faulting and sediment deposition throughout this region. Faulting began approximately at the onset of silicic eruptions ca. 16.5 Ma (Coble and Mahood, 2012), rapidly creating sediment accommodation in fault hanging walls. Silicic eruptions occurred frequently along the SRP from its inception ca 16.5 to the present. For these reasons, any volcanic material that spent large amounts of time being reworked at the surface would have a high probability of including material from younger eruptions.

For isotopically dated samples, maximum and absolute depositional ages from sedimentary rocks and tuffs were determined by estimating the weighted mean of the youngest coherent group of ages (Fig. S2). In several cases, the youngest coherent group was straightforwardly identified as those whose ages overlapped within $2 \sigma$ uncertainty and were clearly younger than others (outside the $2 \sigma$ error bounds). In less clear cases, the youngest coherent group was determined in an interpretive fashion that attempted to maximize the number of included grains while avoiding inclusion of so many grains as to significantly increase age uncertainty. All but one of such cases yielded mean square weighted deviation (MSWD) 1.0. That case (sample 15JLS002; Fig. S2b) yielded MSWD $=0.42$ because of several relatively young grains, but the weighted mean age that would produce MSWD $=1$ is also shown. 
Data from the stratigraphic sections shown in Fig. 5 are compiled together into a generalized column (Fig. 6) based on the preferred depositional ages listed in Tables S1 and S3 herein, as well as the supplementary tables available from EarthChem

(https://doi.org/10.26022/IEDA/112062). The preferred ages for samples previously analyzed for stable isotope values (which do not all have isotopic ages) were assigned by assuming constant sedimentation rates between horizons with age constraints as shown in Fig. 5, although we are aware that constant deposition was unlikely. Hence, vertical error bars in Fig. 6 indicate the full range of permissible ages for individual analyses between minimum and maximum age brackets, conservatively incorporating the full $2 \sigma$ uncertainties of the bounding weighted mean ages. 


\section{TEXT S3. RESULTS OF U-PB DETRITAL ZIRCON GEOCHRONOLOGY}

A sandstone sample (15JLS015) collected from near the top of a thin $(<200 \mathrm{~m})$ sedimentary deposit below the tuff of Hackwood Ranch (Fig. 4a) yielded an MDA of $29.9 \pm 0.2$ Ma on the basis of the weighted mean of 45 analyses (Figs. 5 and S2a). Lund Snee et al. (2016) obtained a U-Pb detrital zircon MDA of $33.9 \pm 0.4 \mathrm{Ma}$ from a sample (10JLS08) collected nearby but stratigraphically lower within the same unit. The age of these deposits is bracketed below by a U-Pb SHRIMP (zircon) age of $37.34 \pm 0.33 \mathrm{Ma}$ (sample 10JLS05) from the tuff of Dixie Creek and above by a ${ }^{40} \mathrm{Ar} /{ }^{39} \mathrm{Ar}$ (sanidine) age of $31.10 \pm 0.47 \mathrm{Ma}$ on the tuff of Hackwood Ranch (Lund Snee et al., 2016). It is unclear why the detrital zircon age of sample 15JLS015 is $\geq 0.5$ Ma younger than the previously obtained ${ }^{40} \mathrm{Ar} /{ }^{39} \mathrm{Ar}$ age of the overlying tuff (including uncertainty), but we take the ${ }^{40} \mathrm{Ar} /{ }^{39} \mathrm{Ar}$ tuff age to be authoritative because multiple samples and isotopic systems have yielded consistent ages (see Lund Snee et al., 2016).

The remaining detrital zircon ages were obtained for samples collected from the latest Oligocene-Miocene Humboldt Formation. Deposition of the Humboldt Formation was previously bracketed to ca. $24.4 \pm 0.1 \mathrm{Ma}$ (U-Pb zircon sample ELM11-PN19) at the bottom to at least $8.2 \pm 0.2 \mathrm{Ma}(\mathrm{U}-\mathrm{Pb}$ zircon sample 12HBD09) at the top (Lund Snee et al., 2016). A tuffaceous sandstone from the western measured sections (Figs. 3 and $4 \mathrm{~b}$ ) representing the stratigraphically lowest Humboldt Formation sample that was analyzed as part of this study (15JLS002, $5 \mathrm{~m}$ above the angular unconformity with underlying Eocene and Oligocene tuffs) extends the oldest known depositional age of this unit to $25.1 \pm 0.2 \mathrm{Ma}$ (a weighted mean of 32 grains). Progressing stratigraphically upward in the western section, a pebble conglomerate with an ashy matrix (sample 15JLS004; $89 \mathrm{~m}$ ) yielded a younger MDA of 21.7 $\pm 0.1 \mathrm{Ma}$ on the basis of a 75-grain weighted mean. One younger grain $(15.7 \pm 0.9 \mathrm{Ma})$ was excluded from this analysis due to obvious zoning, which is why we consider this analysis of a tuffaceous bed to be an MDA rather than an absolute depositional age; it is therefore possible that this sample could be ca. $16 \mathrm{Ma}$ or younger, although the sample's stratigraphic position near and below samples containing only significantly older ages discounts this possibility. Slightly above $(101 \mathrm{~m})$, a weighted mean of 3 analyses established an MDA of $18.4 \pm 2.5 \mathrm{Ma}$ for a matrix-supported pebble conglomerate (sample 15JLS029). Finally, an ashy sandstone (15JLS017) yielded a younger MDA of $16.6 \pm 0.3 \mathrm{Ma}$ from 8 grains. Four previously published approximately 
absolute depositional ages from tuffs higher in this section young progressively upward to ca. 14.6 Ma (Fig. 5) (Lund Snee et al., 2016).

A second Humboldt Formation section was sampled farther east (Figs. 3 and 4c), across a normal fault with $>700 \mathrm{~m}$ throw that exposes the base of the Humboldt Formation in its footwall (Wallace et al., 2008; Lund Snee and Miller, 2015; Lund Snee et al., 2016). The currently available ages within this redundant basal section are not as well constrained as to the west. However, it is quite unlikely that samples from this eastern section were deposited after 9.91 Ma, which is the youngest depositional age obtained by Wallace et al. (2008) using isotopic dating methods and tephra correlations on tuffs collected farther up-section, east of Huntington Creek (Fig. 3). Stratigraphically higher in this same area, Lund Snee et al. (2016) reported a U-Pb detrital zircon age of $8.2 \pm 0.2 \mathrm{Ma}$ (sample 12HBD09), representing the youngest known MDA for the Humboldt Formation (Fig. 3).

A third Humboldt Formation section was sampled to the northeast, west of the Lee township (Figs. 3 and 4d), and roughly along strike of a section along Huntington Creek from which Wallace et al., (2008) reported tuff (absolute depositional) ages that decrease upward from 15.31-9.91 Ma. An approximately absolute depositional age of 14.9 $\pm 0.2 \mathrm{Ma}$ was established based on a 3-grain weighted mean for a tephra sample (15JLS041) collected from the base of the section $(0 \mathrm{~m})$. Near the top of this section $(325 \mathrm{~m})$, a silty sandstone (sample 15JLS037) yielded an MDA of $12.4 \pm 1.0 \mathrm{Ma}$ based on a 3-grain weighted mean. 


\section{TEXT S4. REVISED STRATIGRAPHIC THICKNESS AND DEPOSITIONAL AGE CONSTRAINTS FOR ELKO BASIN SEDIMENTARY ROCKS, NORTHEAST NEVADA}

This section provides detailed information regarding how stratigraphic thicknesses were determined and how age constraints were applied throughout the stratigraphic sections presented in Figs. 5 and 6. Sample localities are shown in Figs. 3 and 4 and listed in the Supplementary Data Tables.

\section{Pliocene-Pleistocene Hay Ranch Formation}

Depositional ages are not well constrained for the Hay Ranch Formation, which is the youngest unit considered in this study. The stable isotope results for this unit that are shown in Fig. 5 were originally obtained by Horton et al. (2004), who did not report sample locations but assigned ages based on assumed sedimentation rates. We assume that these samples were collected from Pine Valley, west of the Piñon Range, in the general location indicated in Fig. 3. Regnier (1960) and Smith and Ketner (1976) provided a tentative depositional age range for the Hay Ranch Formation of middle Pliocene to middle Pleistocene. We therefore assume a permissible depositional age range of 3.6-1.8 Ma for Horton et al.’s samples. Lacking information about stratigraphic depths, for visualization purposes in Fig. 6 we plot all samples as being deposited at the same time, and we retain the full permissible depositional age ranges in the error bars.

\section{Latest Oligocene-Miocene Humboldt Formation}

The latest Oligocene to Miocene Humboldt Formation (Sharp, 1939) is described in detail by Wallace et al. (2008), Lund Snee (2013), Lund Snee and Miller (2015), and Lund Snee et al. (2016). Lund Snee et al. (2016) observed a clear pattern of upward-younging ages for tuffs sampled within the Humboldt Formation. For the present study, we collected additional samples for geochronology and stable isotope analysis in several measured sections shown in Fig. 5, which add to the geochronologic data presented by Lund Snee et al. (2016). The lowest exposed levels of the Humboldt Formation were sampled in two subparallel sections near the westernmost exposures of the Humboldt Formation in the studied area, as well as a third "eastern base Humboldt Formation" section northeast of Cedar Ridge (shown in Figs. 3 and 4), for 
redundancy across this important interval. Samples are described from older to younger in each of these sections.

Using map relationships, stratigraphic thicknesses and depositional age constraints, the two western sections were compiled together in the "composite western base Humboldt Formation" section (Figs. 4b and 5). In our thickness measurements for this compiled section, we accounted for minor observed offset and duplication of Humboldt Formation strata across an east-striking fault in the northern of the two sections ( $48 \mathrm{~m}$ stratigraphic thickness duplicated). An absolute maximum age constraint for this section (and for the Humboldt Formation across the area) is $31.08 \pm 0.47 \mathrm{Ma}\left({ }^{40} \mathrm{Ar} /{ }^{39} \mathrm{Ar}\right.$ sanidine), our preferred age obtained for the tuff of Hackwood Ranch, which the Humboldt Formation overlies across a poorly exposed angular unconformity (Lund Snee et al., 2016). Above this, only a few meters above the base of this unit in the composite western section, we obtained a U-Pb detrital zircon depositional age of $25.1 \pm$ 0.2 Ma (Fig. S2b) from a sample of air-fall tuff deposited within the Humboldt Formation (sample 15JLS002; Fig. 4b). Lund Snee et al. (2016) obtained a U-Pb detrital zircon MDA of $24.4 \pm 0.1 \mathrm{Ma}$ from their sample ELM11-PN19, collected from about $60 \mathrm{~m}$ stratigraphically above 15JLS002, also from a probable air-fall tuff deposited within the Humboldt Formation, which provides another approximate absolute depositional age for that low stratigraphic level (Fig. 5). Together, these progressively younger ages within the Humboldt Formation reveal minor but sustained lacustrine deposition well before major surface-breaking extension initiated ca. 17-16 Ma (Colgan and Henry, 2009; Colgan et al., 2010; Lund Snee et al., 2016).

Overlying sample 15JLS004 yielded an MDA of 21.7 $\pm 0.1 \mathrm{Ma}$ based on a weighted mean of 75 grains (Fig. S2c). A single grain in sample 15JLS004 that displayed obvious zoning was omitted, but the earlier part of this grain's analytical time series yielded a young age of 15.7 $\pm 0.9 \mathrm{Ma}$. Hence, we note that it is possible that sample 15JLS004 (and those above it) may be ca. 15.7 Ma or younger, but the tenuous nature of this zoned single grain age and the sample's stratigraphic position (near and below samples containing only older ages) makes that possibility less likely. Although the large population of grains ca. $22 \mathrm{Ma}$ (Fig. S2c) in this sample $(n=91)$ suggests that it may represent a reworked air-fall tuff, we conservatively do not treat this sample as a bound on minimum depositional ages for underlying strata due to the uncertainty related to the possible younger grain. Sample 15JLS027A yielded a poorly constrained MDA of $25.3 \pm 1.2$ Ma based on a single zircon grain (older than age constraints beneath it). Stratigraphically 
overlying sample 15JLS029 (from the northern section) yielded an MDA of 18.4 $\pm 2.5 \mathrm{Ma}$, based on a weighted mean of 3 ages (Fig. S2f).

A weighted mean age of $16.6 \pm 0.3$ (Fig. S2d), from 8 grains, is established for a higher sample from the southern section, 15JLS017. This sample provides an MDA for the stratigraphically overlying stable isotope analyses by Mulch et al. (2015) and sources therein. Consequently, an outcome of this work is that $>400 \mathrm{~m}$ of Humboldt Formation section are present below the lowest samples for which published stable isotope values are available. A minimum depositional age of $15.53 \mathrm{Ma}$ is assigned to these older stable isotope samples (and to stratigraphically underlying rocks), based on a $\mathrm{U}-\mathrm{Pb}$ detrital zircon age of $15.6 \pm 0.1 \mathrm{Ma}$ obtained by Lund Snee et al. (2016) for air-fall tuff sample Tiws-J4 (Fig. 5). Higher in this composite section, approximate absolute depositional ages reported by Lund Snee et al. (2016) on upward-younging, intercalated air-fall tuffs provide maximum and minimum depositional age constraints on overlying and underlying strata, respectively (Fig. 5). These ages enable us to assign depositional age bounds on the stable isotope samples reported by Mulch et al. (2015) and sources therein for the upper (northern) portions of their "Indian Well Formation" section as well (see Figs. 3, 4b, and 5). (Note that Lund Snee et al., 2016, recommended that the Indian Well Formation name be discontinued after they found that essentially all sedimentary strata previously included within it are latest Oligocene to Miocene in age and belong to the Humboldt Formation based on detailed re-mapping of the section by Lund Snee and Miller, 2015).

The eastern section, which also contains the base of the Humboldt Formation, is exposed $\sim 8 \mathrm{~km}$ away from the western section described above, on the northeast side of Cedar Ridge (Figs. 3 and 4c), across a normal fault system that duplicates the Cenozoic succession (Wallace et al., 2008; Lund Snee and Miller, 2015; Lund Snee et al., 2016). In the eastern section, strata of the Humboldt Formation were deposited unconformably above rocks resembling the Eocene Elko Formation and Late Cretaceous(?)-Eocene(?) limestone (TKl) and conglomerate, sandstone, siltstone, and limestone (TKcs) units (Lund Snee and Miller, 2015; Lund Snee et al., 2016). Unlike the composite basal section exposed farther west, detrital U-Pb zircon analyses carried out in this succession (sample 12HBD06 of Lund Snee et al., 2016, and sample $15 J L S 036 \mathrm{~B}$ of this study) record no grains in the age range between the end of local volcanic activity ca. $37 \mathrm{Ma}$ and the onset of rapid extension ca. 17-16 Ma (Colgan et al., 2010; Lund Snee et al., 2016). The lowest sample collected near the base of the Humboldt Formation (sample 
12HBD06 of Lund Snee et al., 2016) contained a single young grain at $15.7 \pm 0.5 \mathrm{Ma}$, which was not employed to constrain an MDA due to its tentative nature. The lack of Cenozoic grains older than 15.7 Ma suggests that sedimentation did not occur in this eastern area in the time span $\sim 26-$ 15.7 Ma, when tuffs were being deposited in the Humboldt Formation succession sampled $\sim 8 \mathrm{~km}$ to the west. Minimum depositional ages are not constrained for the eastern basal Humboldt Formation section (Figs. 3 and 4c) because sample 15JLS036B (Fig. S2g) yielded only a single $\mathrm{U}-\mathrm{Pb}$ zircon age $(11.5 \pm 0.4 \mathrm{Ma})$. However, it is quite unlikely that samples from this eastern section were deposited after 9.91 Ma, which is the youngest depositional age obtained by Wallace et al. (2008) using isotopic dating methods and tephra correlations on tuffs collected farther up-section, east of Huntington Creek (Fig. 4d).

Finally, we sampled a fourth Humboldt Formation section to the northeast of the others, near the Lee township (Figs. 3, 4d, and 5), part of which Chamberlain et al. (2012) and Mulch et al. (2015) previously sampled for stable isotope values but did not provide age constraints. We have bracketed the MDA for this succession with a U-Pb detrital zircon age of $14.9 \pm 0.2 \mathrm{Ma}$ obtained on tuff sample 15JLS041, from the base of the section (Figs. S2i, 4d, and 5). We account for local duplication by open folds shown in Fig. 4d, as well as minor, outcrop-scale normal faults. At the top of the section, we obtained a U-Pb detrital zircon MDA of $12.4 \pm 1.0$ Ma, on sample 15JLS037 (Fig. S2h). Although this MDA does not provide an upper (minimum) age constraint, the section is approximately along strike from (and $\sim 5 \mathrm{~km}$ away from) the Humboldt Formation type section on the eastern banks of Huntington Creek (Sharp, 1939) in which Wallace et al. (2008) found air-fall tuff depositional ages ranging from 15.31 Ma at the base to $9.91 \mathrm{Ma}$ at the top (Fig. 3). The youngest detrital zircon MDA obtained for the Humboldt Formation in Huntington Valley is $8.2 \pm 0.2 \mathrm{Ma}$ (Lund Snee et al., 2016, sample 12HBD09), from a sample collected $\sim 10 \mathrm{~km}$ southwest of the Lee section sampled in this study. We assign best ages to the stable isotope values previously obtained from the Lee section ranging between 14.39-13.38 Ma considering the above information and assuming constant sedimentation rates, but we allow the uncertainty bars plotted in Fig. 6 to span as young as 8.01 Ma.

\section{Eocene-Oligocene sandstone and siltstone between the Eocene tuff of Dixie Creek and the Oligocene tuff of Hackwood Ranch}


A thin $(<200 \mathrm{~m})$ deposit of sandstone and siltstone is exposed near the abandoned Hackwood Ranch site (Figs. 3 and 4a). The depositional ages for these strata are bracketed by a $36.84 \pm 0.34 \mathrm{Ma}(\mathrm{U}-\mathrm{Pb}$ zircon SHRIMP) age for the unconformably underlying tuff of Dixie Creek and multiple 31.10 Ma $\left({ }^{40} \mathrm{Ar} /{ }^{39} \mathrm{Ar}\right.$ sanidine and U-Pb zircon SHRIMP) eruptive ages for the overlying tuff of Hackwood Ranch (Lund Snee et al., 2016). Hence, deposition of this sedimentary succession occurred across the time interval 37.18 to ca. $31 \mathrm{Ma}$. In addition, Lund Snee et al. (2016) reported a U-Pb detrital zircon MDA of 33.9 \pm 0.4 Ma for a sample (10JLS08) collected from the lower parts of this interval, and we (this study) obtained a U-Pb detrital zircon MDA of 29.9 $\pm 0.2 \mathrm{Ma}$ for a sample (15JLS015) collected from near the top of the succession, based on a weighted mean of 45 grains (Figs. 4a, 5, and S2a). Two grains were omitted due to the indication of zoning in their time series. It is unclear why this upper MDA is $\geq 0.5 \mathrm{Ma}$ younger than (outside of the uncertainty range of) the age of the overlying tuff of Hackwood Ranch. As noted above, we consider the previously reported ca. $31 \mathrm{Ma}$ ages for the tuff of Hackwood Ranch to be definitive due to the consistency of these ages across multiple isotopic systems (Lund Snee et al., 2016), and the expectation that single collector LA-ICP-MS analysis could be less accurate than U-Pb SHRIMP or ${ }^{40} \mathrm{Ar} /{ }^{39} \mathrm{Ar}$. Stable isotope values are not available for this section, but ages for these rocks are reported here because they nevertheless document localized sediment accumulation during that time span.

\section{Eocene Elko Formation}

Across the Elko Basin, the beginning of Elko Formation deposition is approximately bracketed by a pink air-fall tuff at low stratigraphic levels in the Elko Hills (Fig. S3) that yielded a U-Pb zircon (SHRIMP) age of $46.1 \pm 0.2$ (sample 00-188GS of Haynes, 2003), which is probably correlative with a less precise $\mathrm{U}-\mathrm{Pb}$ detrital zircon age of $45.92 \pm 0.95 \mathrm{Ma}$ obtained by Lund Snee et al. (2016) farther south (sample ELKO-1). Here we take the more precise $46.10 \pm$ $0.20 \mathrm{Ma}$ age obtained by Haynes (2003) to conservatively suggest an approximate start of Elko Formation deposition at $46.30 \mathrm{Ma}$ (including the $2 \sigma$ uncertainty). An eruptive age of $38.47 \pm$ $0.15 \mathrm{Ma}\left({ }^{40} \mathrm{Ar} /{ }^{39} \mathrm{Ar}\right.$ plagioclase$)$ obtained from a basal eruptive unit within the overlying tuff of Dixie Creek (sample H10-45 of Henry et al., 2015) provides a minimum depositional age of 38.32 Ma for the Elko Formation. A U-Pb detrital zircon weighted mean age of $37.9 \pm 0.5 \mathrm{Ma}$ from the eastern Piñon Range (sample ELKO-2 of Lund Snee et al., 2016) indicates that 
deposition of the Elko Formation continued at least to that time, bracketing the youngest Elko Formation deposition to around ca. $38.4 \mathrm{Ma}$ (accounting for $2 \sigma$ uncertainties). The ages of the uppermost Elko Formation strata and the lowermost overlying tuffs suggest that Elko Formation deposition continued until the onset of volcanism in this area.

None of these bracketing ages were obtained from samples collected within the immediate area of the Elko Formation section studied for stable isotope values by Horton et al. (2004) and subsequent studies (Mix et al., 2011; Chamberlain et al., 2012; Mulch et al., 2015), which is located near Emigrant Spring (Fig. 3). However, Mulch et al. (2015) obtained ${ }^{40} \mathrm{Ar} /{ }^{39} \mathrm{Ar}$ ages from detrital biotite collected across this same section, which permit establishment of MDAs throughout the sampled section. With one exception, these MDAs young upward, which could indicate that some of them represent air- or water-lain tuffs that originated from nearby eruptions of similar ages (Ressel and Henry, 2006). Accounting for this possibility, in Fig. 6 we select a best estimate of actual depositional age for each sample according to the possibility that some of the ages provided by Mulch et al. (2015) could represent absolute depositional ages, but we conservatively plot error bars that extend upward to the true minimum depositional age bound of 38.32 Ma provided by tuff sample H10-45 of Henry et al. (2015).

Horton et al. (2004) assigned additional samples at the base of this section to underlying "Cherty Limestone" and "Limestone and Limestone clast Conglomerate" units (the same samples were assigned to units called "Cherty Limestone" and "Limestone and Conglomerate" by Mulch et al., 2015). Mulch et al. (2015) reported that these samples were collected from a section near Emigrant Spring (Fig. 4). However, Horton et al. (2004) did not report sample locations, so the exact stratigraphic assignment and age cannot be determined. Horton et al. (2004, p. 864) identified these rocks as belonging to the "non-volcanic sequence" of early Cenozoic strata that precedes the Elko Formation, which would make them older than ca. 46 Ma. In contrast, Mulch et al. (2015) and Ibarra et al. (2021) placed the 46.1 Ma tuff age obtained by Haynes (2003) between the "Cherty Limestone" and "Limestone and Conglomerate" units, based on stratigraphic assignments made farther north in the Elko Hills (Fig. 3), implying that the overlying "Cherty Limestone" is younger than 46.1 Ma and the "Limestone and Conglomerate" is older. Further adding to the confusion, Ibarra et al. (2021) correlated the "Cherty Limestone" (see their Fig. 1) with the Late Cretaceous(?)-early Eocene(?) limestone (TK1) of Smith and Ketner (1976) and Lund Snee et al. (2016) that is exposed in the "east of Red Spring section" 
northeast of Cedar Ridge (Fig. 3). The TKl unit is by definition pre-volcanic and hence is older than 46.1 Ma (see next subsection, below).

The confusion about the age of the "Cherty Limestone" unit may be at least partly resolved by the recent observation of Cenozoic volcanic clasts in a basal conglomerate within the Elko Formation from which a U-Pb zircon MDA of $44.5 \pm 0.9 \mathrm{Ma}$ was also obtained (sample EmigZr7 of Hollingsworth et al., 2017). This sample was collected from 50-85 $\mathrm{m}$ above the unconformity with underlying Paleozoic rocks at the Emigrant mine location (Ressel et al., 2015), which is $\sim 3.5 \mathrm{~km}$ north of the Emigrant Spring section studied by Horton et al. (2004), Mulch et al. (2015), and Ibarra et al. (2021) and included in this study (Figs. 5 and 6). For this reason, the strata that were previously assigned by Horton et al. (2004), Mulch et al. (2015), and Ibarra et al. (2021) to underlying units called "Cherty Limestone" and "Limestone and Conglomerate" (and similar) most likely belong to the lower part of the Elko Formation and are probably for the most part $45.4 \mathrm{Ma}$ and younger, counting the $2 \sigma$ age uncertainty (Figs. 5 and 6). Because that age was not obtained from a sample from the absolute bottom of the Elko Formation, we conservatively assign these basal Elko Formation strata an older MDA constraint of 46.3 Ma, the oldest age obtained from the Elko Formation ( $2 \sigma$ uncertainty range of sample 00 188GS of Haynes, 2003, as noted above). Based on these age constraints, we assign a preferred depositional age of 45.0 Ma to the stratigraphically lowest "Limestone and Conglomerate" sample in Fig. 5 (TL04-02). Because locations and stratigraphic depth information are not available for this unit and the "Cherty Limestone" of Horton et al. (2004), Mulch et al. (2015), and Ibarra et al. (2021), we assign best ages that decrease upward in increments of $0.1 \mathrm{Ma}$ (to 44.3 Ma). As with some of the overlying strata of the middle Elko Formation described above, we employ a minimum depositional age bound of 41.2 Ma for these units, based on the $2 \sigma$ range for the $41.60 \pm 0.40$ Ma reworked sediments analyzed by Mulch et al. (2015).

Finally, Smith et al. (2017) argued that the ${ }^{40} \mathrm{Ar} /{ }^{39} \mathrm{Ar}$ biotite ages determined by Mulch et al. (2015) and used to constrain depositional ages within the Elko Formation prior to the negative shift in $\delta^{18} \mathrm{O}$ values were erroneously young. On this basis, they argued that Elko Formation deposition ceased by ca. $40.4 \mathrm{Ma}$, earlier than previously reported and prior to the ca. $40 \mathrm{Ma}$ Middle Eocene Climatic Optimum (MECO) event (Sluijs et al., 2013). However, as explained above, multiple mineral and isotopic systems indicate that the end of Elko Formation deposition is tightly constrained to ca. $38.4 \mathrm{Ma}$, which is at odds with this $\sim 2 \mathrm{Myr}$ older estimate by Smith 
et al. (2017). Smith et al. (2017) suggested that the ${ }^{40} \mathrm{Ar} /{ }^{39} \mathrm{Ar}$ biotite ages previously obtained by Mulch et al. (2015) were $\sim 2$ Myr too young, and from this they proposed discounting the use of biotite ${ }^{40} \mathrm{Ar} /{ }^{39} \mathrm{Ar}$ ages in general for precise geochronologic applications. It is not clear why Smith et al. (2017) obtained systematically (ca. 1.5-2.0 Ma) older single-crystal sanidine ${ }^{40} \mathrm{Ar} /{ }^{39} \mathrm{Ar}$ ages on some of the same strata, but it is possible that their analyses were conducted on detrital grains that were older than the true sedimentary depositional ages. Moreover, unpublished sanidine ${ }^{40} \mathrm{Ar} /{ }^{39} \mathrm{Ar}$ ages by Mulch et al. (2015), from the same Elko Formation strata, agree closely with their ${ }^{40} \mathrm{Ar} /{ }^{39} \mathrm{Ar}$ biotite ages; the unpublished sanidine ages are slightly younger (by $0.3-0.8 \mathrm{Ma}$ ) than the biotite ages and indistinguishable within $2 \sigma$ error (M. Cosca, 2019, pers. comm.). Hence we interpret that the detrital biotite and sanidine ${ }^{40} \mathrm{Ar} /{ }^{39} \mathrm{Ar}$ MDAs reported by Mulch et al. (2015) are closest to the true depositional ages for Elko Formation strata.

\section{Late Cretaceous(?)-early Eocene(?) limestone (TKI) and conglomerate, sandstone, siltstone, and limestone (TKes)}

Late Cretaceous(?)-early Eocene(?) limestone (TKl) and conglomerate, sandstone, siltstone, and limestone (TKcs) units underlie the Elko Formation near Cedar Ridge (Figs. 3 and 4) and are apparently older than the oldest strata sampled for this study (Fig. 5). Hence, these units are likely older than $46.10 \pm 0.20 \mathrm{Ma}$, which is the age of the oldest volcanic tuff observed at the base of the Elko Formation (sample 00-188GS of Haynes, 2003). The MDA of these underlying sediments is constrained only by the presence of fossils "younger than Jurassic" (I.G. Sohn in Smith and Ketner, 1976), with the bulk of fossil evidence provided by Smith and Ketner (1976) pointing to deposition during Late Cretaceous time or later, and a youngest detrital zircon population of $240 \mathrm{Ma}$ (sample ELM11-PN16 of Lund Snee et al., 2016). Based on this information, we assume that the likeliest age for units TKcs and TK1 is Late Cretaceous-Eocene (100 Ma to $45.9 \mathrm{Ma}$, counting the $2 \sigma$ error for sample 00-188GS). The limestone unit (TKl) is thought to be slightly younger than the clastic unit (TKcs) on the basis of its generally higher stratigraphic position, although they could be partially contemporaneous (Lund Snee et al., 2016). We note that Ketner and Alpha (1992) argued that the "cherty limestone" and "conglomerate" facies in the Emigrant Spring area and elsewhere should be included within the Eocene Elko Formation due to apparently conformable relations with the overlying Elko 
Formation rocks and because similar cherty limestone and conglomerate rocks are clearly part of the lower Elko Formation farther north in the Elko Hills (Fig. 3). Despite this, we consider the conspicuous lack of Cenozoic volcanic detritus in these older rocks within the study area to be diagnostic and to potentially provide important information about stratigraphic age. Hence, we follow Smith and Ketner (1976), Lund Snee (2013), and Lund Snee and Miller (2015) and separate the TKcs and TK1 units from the younger Elko Formation where these sediments demonstrably lack Cenozoic detritus. 

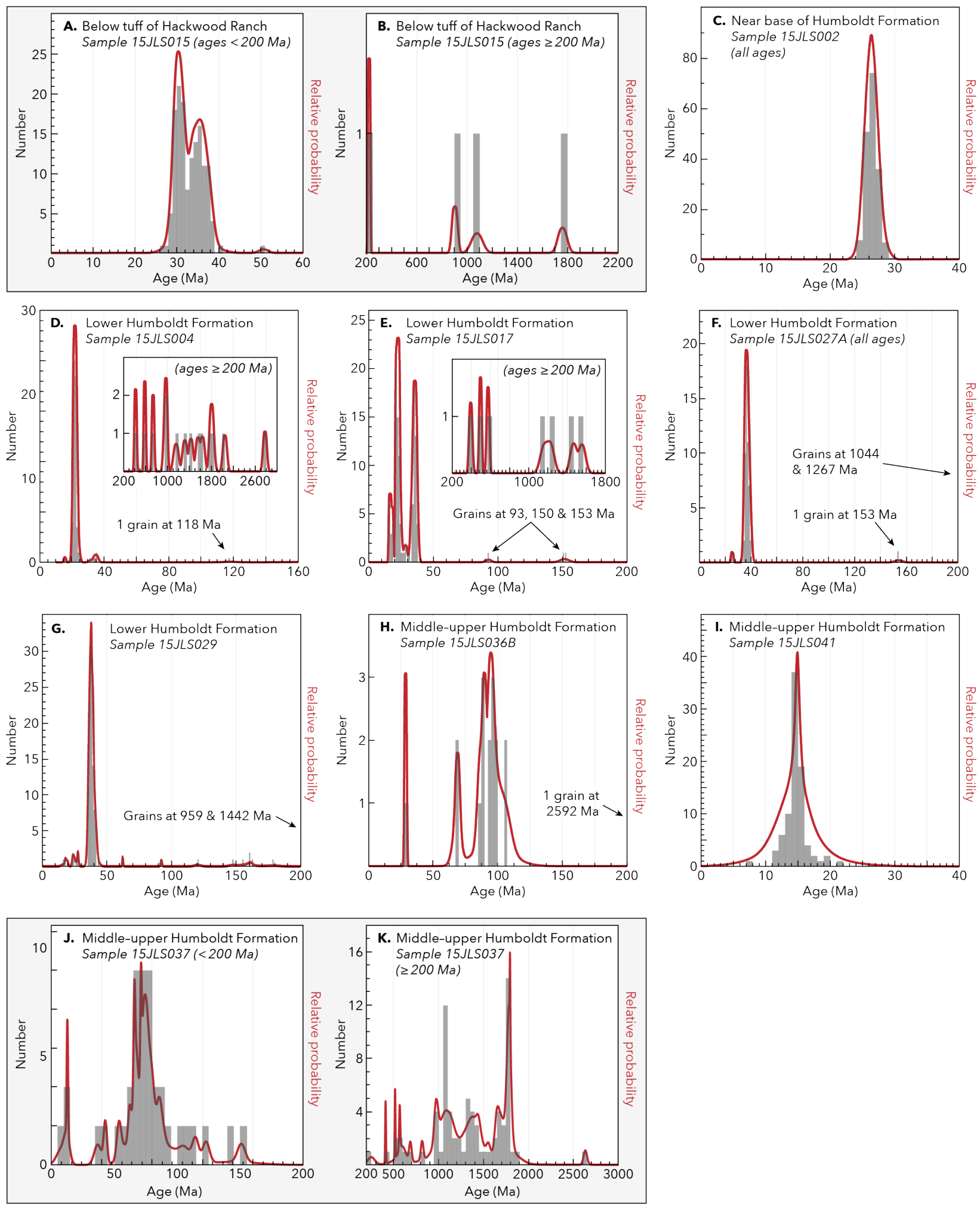

Fig. S1. Probability density plots of detrital zircon U-Pb ages. 

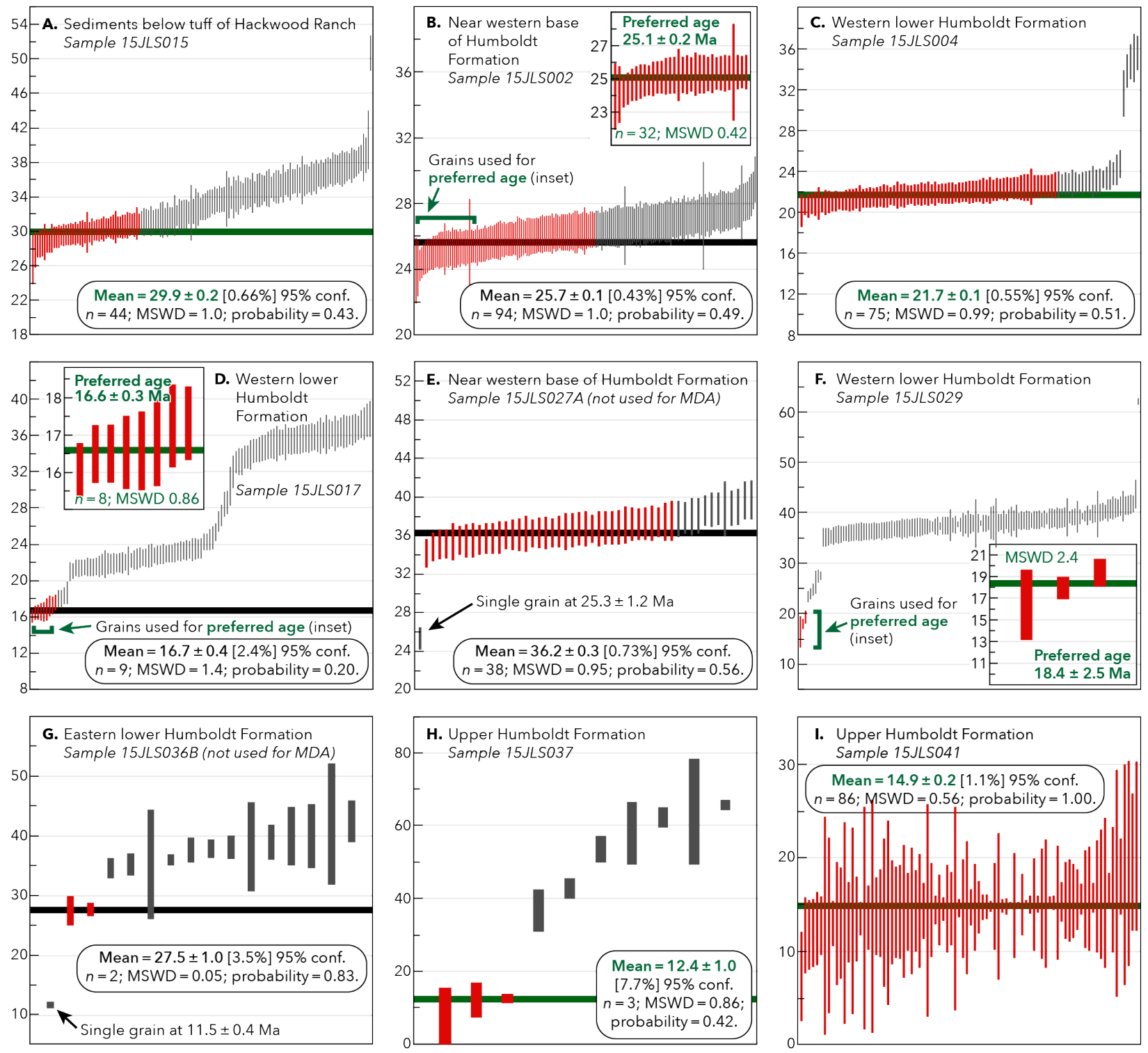

Fig. S2. Weighted mean plots for the youngest coherent groups of detrital zircon U-Pb analyses obtained from each sample, defining depositional ages or maximum depositional ages. Preferred ages are indicated in green and are also given in Table S1. Non-preferred weighted mean ages (black) are given to indicate the youngest group of ages yielding MSWD $\sim 1$. Red bars represent the ages employed to determine the maximum depositional age shown on each plot, whereas dark gray bars indicate other ages that were not employed in the maximum depositional age calculation. Weighted by data-point errors only. Box heights represent $2 \sigma$ errors. MSWD $=$ mean square weighted deviation. 


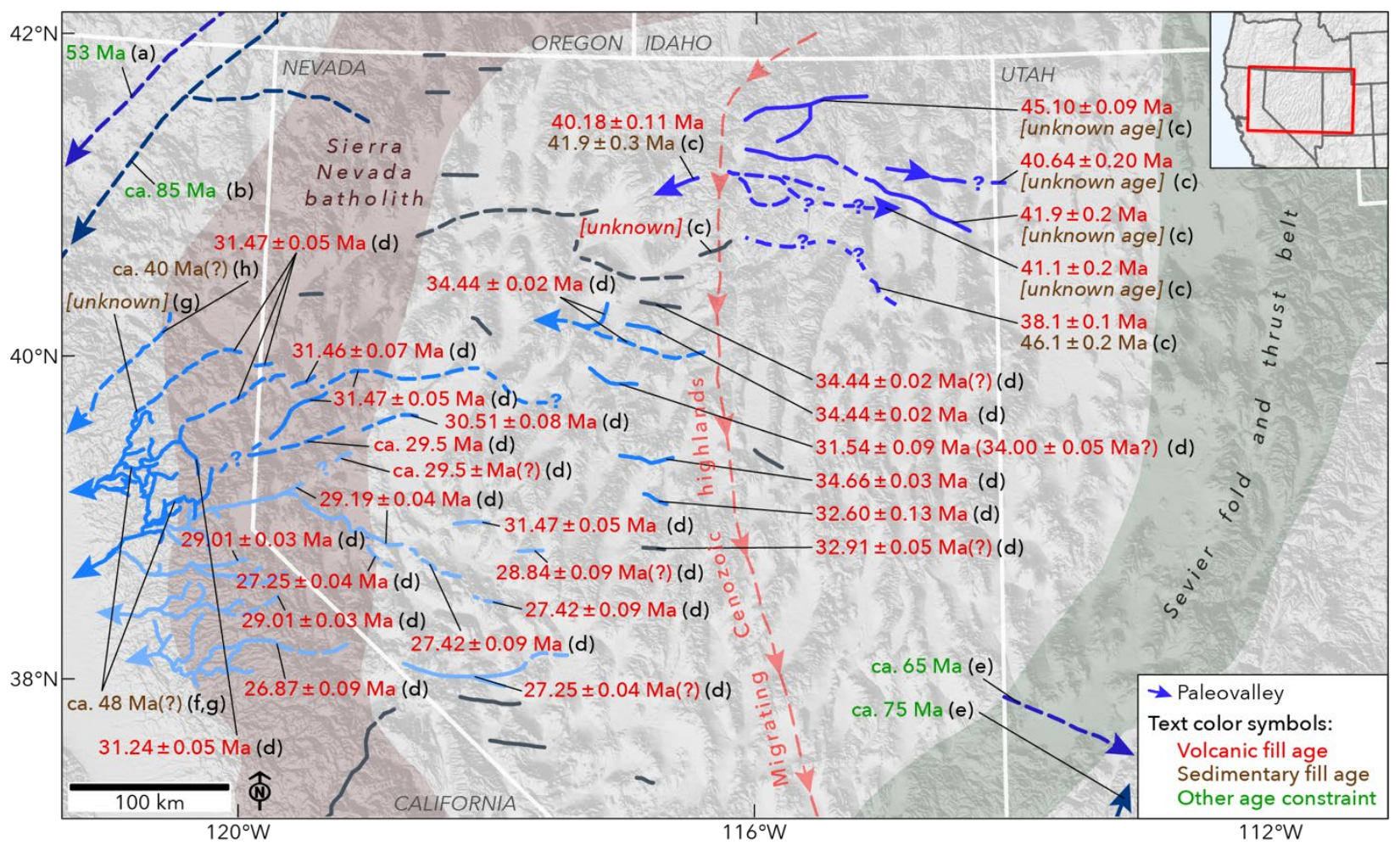

Fig. S3. Map of paleovalleys from the Great Basin and surroundings, western USA, with data sources and ages of oldest fill material or onset of drainage activity indicated. Paleovalley locations are from Henry et al. (2012), Henry and John (2013), Dumitru et al. (2015, 2016), and sources therein. Oldest sedimentary and/or volcanic fill identified in each paleovalley are indicated (orange and red type, respectively). Ages of pre-volcanic sedimentary fill are not well constrained. Grey paleovalleys indicate no relevant age constraints. The Sevier fold and thrust belt is from DeCelles (2004). The Cretaceous Sierra Nevada arc is after Van Buer and Miller (2010). This figure complements Fig. 2, providing additional age information and references. (a) — Dumitru et al. (2015); (b) —Dumitru et al. (2016); (c)—Henry (2008); (d)—Henry and John (2013); (e)—Goldstrand (1992, 1994); (f)—MacGinitie (1941); (g)— Yeend (1974); (h) — Garside et al. (2005). 


\section{REFERENCES}

Andersen, T., Elburg, M.A., and Magwaza, B.N., 2019, Sources of bias in detrital zircon geochronology: Discordance, concealed lead loss and common lead correction: EarthScience Reviews, v. 197, p. 102899, doi:10.1016/j.earscirev.2019.102899.

Black, L.P. et al., 2004, Improved ${ }^{206} \mathrm{~Pb} /{ }^{238} \mathrm{U}$ microprobe geochronology by the monitoring of a trace-element-related matrix effect; SHRIMP, ID-TIMS, ELA-ICP-MS and oxygen isotope documentation for a series of zircon standards: Chemical Geology, v. 205, p. 115140, doi:10.1016/j.chemgeo.2004.01.003.

Van Buer, N.J., and Miller, E.L., 2010, Sahwave batholith, NW Nevada: Cretaceous arc flare-up in a basinal terrane: Lithosphere, v. 2, p. 423-446, doi:10.1130/L105.1.

Chamberlain, C.P., Mix, H.T., Mulch, A., Hren, M.T., Kent-Corson, M.L., Davis, S.J., Horton, T.W., and Graham, S.A., 2012, The Cenozoic climatic and topographic evolution of the western North American Cordillera: American Journal of Science, v. 312, p. 213-262, doi:10.2475/02.2012.05.

Coble, M.A., and Mahood, G.A., 2012, Initial impingement of the Yellowstone plume located by widespread silicic volcanism contemporaneous with Columbia River flood basalts: Geology, v. 40, p. 655-658, doi:10.1130/G32692.1.

Colgan, J.P., and Henry, C.D., 2009, Rapid middle Miocene collapse of the Mesozoic orogenic plateau in north-central Nevada: International Geology Review, v. 51, p. 920-961, doi:10.1080/00206810903056731.

Colgan, J.P., Howard, K.A., Fleck, R.J., and Wooden, J.L.P., 2010, Rapid middle Miocene extension and unroofing of the southern Ruby Mountains, Nevada: Tectonics, v. 29, p. 417, doi:10.1029/2009TC002655.

DeCelles, P.G., 2004, Late Jurassic to Eocene evolution of the Cordilleran thrust belt and foreland basin system, western U.S.A.: American Journal of Science, v. 304, p. 105-168, doi:10.2475/ajs.304.2.105.

Dumitru, T.A., Elder, W.P., Hourigan, J.K., Chapman, A.D., Graham, S.A., and Wakabayashi, J., 2016, Four Cordilleran paleorivers that connected Sevier thrust zones in Idaho to depocenters in California, Washington, Wyoming, and, indirectly, Alaska: Geology, v. 44, p. 75-78, doi:10.1130/G37286.1. 
Dumitru, T.A., Ernst, W.G., Hourigan, J.K., and McLaughlin, R.J., 2015, Detrital zircon U-Pb reconnaissance of the Franciscan subduction complex in northwestern California: International Geology Review, v. 57, p. 767-800, doi:10.1080/00206814.2015.1008060.

Dumitru, T.A., and Stockli, D.F., 1998, A better way to separate apatite from zircon using constriction tubes: Advances in Fission-Track Geochronology, p. 325-330.

Garside, L.J., Henry, C.D., Faulds, J.E., and Hinz, N.H., 2005, The upper reaches of the Sierra Nevada auriferous gold channels, California and Nevada: Geological Society of Nevada Symposium, p. 209-235.

Gehrels, G.E., Valencia, V.A., and Pullen, A., 2006, Detrital zircon geochronology by laserablation multicollector ICPMS at the Arizona Laserchron Center: Geochronology: Emerging Opportunities, v. 12, p. 67-76.

Gehrels, G.E., Valencia, V.A., and Ruiz, J., 2008, Enhanced precision, accuracy, efficiency, and spatial resolution of $\mathrm{U}-\mathrm{Pb}$ ages by laser ablation-multicollector-inductively coupled plasmamass spectrometry: Geochemistry, Geophysics, Geosystems, v. 9, p. 1-13, doi:10.1029/2007GC001805.

Goldstrand, P.M., 1992, Evolution of Late Cretaceous and early Tertiary basins of southwest Utah based on clastic petrology: Journal of Sedimentary Research, v. Vol. 62, p. 495-507, doi:10.1306/D4267933-2B26-11D7-8648000102C1865D.

Goldstrand, P.M., 1994, Tectonic development of Upper Cretaceous to Eocene strata of southwestern Utah: Bulletin of the Geological Society of America, v. 106, p. 145-154, doi:10.1130/0016-7606(1994)106<0145.

Haynes, S.R., 2003, Development of the Eocene Elko Basin, northeastern Nevada: Implications for paleogeography and regional tectonism: The University of British Columbia, https://circle.ubc.ca/bitstream/id/34598/ubc_2003-0240.pdf.

Henry, C.D., 2008, Ash-flow tuffs and paleovalleys in northeastern Nevada: Implications for Eocene paleogeography and extension in the Sevier hinterland, northern Great Basin: Geosphere, v. 4, p. 1-35, doi:10.1130/GES00122.1.

Henry, C.D., Hinz, N.H., Faulds, J.E., Colgan, J.P., John, D.A., Brooks, E.R., Cassel, E.J., Garside, L.J., Davis, D.A., and Castor, S.B., 2012, Eocene-Early Miocene paleotopography of the Sierra Nevada-Great Basin-Nevadaplano based on widespread ash-flow tuffs and paleovalleys: Geosphere, v. 8, p. 1-27, doi:10.1130/GES00727.1. 
Henry, C.D., Jackson, M.R., Mathewson, D.C., Koehler, S.R., and Moore, S.C., 2015, Eocene igneous geology and relation to mineralization: Railroad district, southern Carlin trend, Nevada, in Pennell, W.M. and Garside, L.J. eds., Geological Society of Nevada, New Concepts and Discoveries, p. 939-965.

Henry, C.D., and John, D.A., 2013, Magmatism, ash-flow tuffs, and calderas of the ignimbrite flareup in the western Nevada volcanic field, Great Basin, USA: Geosphere, v. 9, p. 951, doi:10.1130/GES00867.1.

Hollingsworth, E.R., Ressel, M.W., and Henry, C.D., 2017, Age and depth of Carlin-type gold deposits in the southern Carlin trend: Eocene Mountain Lakes, Big Volcanoes, and Widespread, Shallow Hydrothermal Circulation, in Bedell, R.L. and Ressel, M.W. eds., Geological Society of Nevada field trip guidebook: Shallow expressions of Carlin-type gold deposits: Alligator Ridge and Emigrant mines, Nevada, Reno, NV, p. 149-173.

Horton, T.W., Sjostrom, D.J., Abruzzese, M.J., Poage, M.A., Waldbauer, J.R., Hren, M.T., Wooden, J.L.P., and Chamberlain, C.P., 2004, Spatial and temporal variation of Cenozoic surface elevation in the Great Basin and Sierra Nevada: American Journal of Science, v. 304, p. 862-888, doi:10.2475/ajs.304.10.862.

Ibarra, D.E., Kukla, T., Methner, K.A., Mulch, A., and Chamberlain, C.P., 2021, Reconstructing Past Elevations From Triple Oxygen Isotopes of Lacustrine Chert: Application to the Eocene Nevadaplano, Elko Basin, Nevada, United States: Frontiers in Earth Science, v. 9, 19 p., doi:10.3389/feart.2021.628868.

Ketner, K.B., and Alpha, A.G., 1992, Mesozoic and tertiary rocks near Elko, Nevada—Evidence for Jurassic to Eocene folding and low-angle faulting: U.S. Geological Survey Bulletin 1988-C, 13 p.

Ludwig, K.R., 2008, User's manual for Isoplot 3.7: A geochronological toolkit for Microsoft Excel: Berkeley Geochronology Center Special Publication No. 4, p. 77.

Lund Snee, J.-E., 2013, Geology and geochronology of Cenozoic units in the Piñon Range and Huntington Valley, Nevada: Stanford University, 263 p., http://purl.stanford.edu/hx388mg6634.

Lund Snee, J.-E., and Miller, E.L., 2015, Preliminary geologic map of Cenozoic units of the central Robinson Mountain volcanic field and northwestern Huntington Valley: Nevada Bureau of Mines and Geology Open File, v. 15-2, p. 42, 1:24,000 scale, 
http://pubs.nbmg.unr.edu/product-p/of2015-02.htm.

Lund Snee, J.-E., Miller, E.L., Grove, M.J., Hourigan, J.K.J.K., and Konstantinou, A., 2016, Cenozoic paleogeographic evolution of the Elko Basin and surrounding region, northeast Nevada: Geosphere, v. 12, p. 464-500, doi:10.1130/GES01198.1.

MacGinitie, H.D., 1941, Contributions to Paleontology: Middle Eocene Flora from the central Sierra Nevada: Washington, D.C., Carnegie Institution of Washington Publication 534.

Mix, H.T., Mulch, A., Kent-Corson, M.L., and Chamberlain, C.P., 2011, Cenozoic migration of topography in the North American Cordillera: Geology, v. 39, p. 87-90, doi:10.1130/G31450.1.

Mulch, A., Chamberlain, C.P., Cosca, M.A., Teyssier, C., Methner, K., Hren, M.T., and Graham, S.A., 2015, Rapid change in high-elevation precipitation patterns of western North America during the Middle Eocene Climatic Optimum (MECO): American Journal of Science, v. 315, p. 317-336, doi:10.2475/04.2015.02.

Naeser, N.D., and Naeser, C.W., 1984, Fission-track dating, in Mahaney, W.C. ed., Quaternary Dating Methods, New York, NY, Elsevier Science Publishing Company Inc., p. 87-100.

Paces, J.B., and Miller, J.D., 1993, Precise U-Pb ages of Duluth Complex and related mafic intrusions, northeastern Minnesota: Geochronological insights to physical, petrogenetic, paleomagnetic, and tectonomagmatic processes associated with the $1.1 \mathrm{Ga}$ Midcontinent Rift System: Journal of Geophysical Research, v. 98, p. 13997, doi:10.1029/93JB01159.

Paton, C., Hellstrom, J., Paul, B., Woodhead, J., and Hergt, J., 2011, Iolite: Freeware for the visualisation and processing of mass spectrometric data: Journal of Analytical Atomic Spectrometry, v. 26, p. 2508, doi:10.1039/c1ja10172b.

Regnier, J., 1960, Cenozoic geology in the vicinity of Carlin, Nevada: Bulletin of the Geological Society of America, v. 71, p. 1189-1210, doi:10.1130/00167606(1960)71[1189:CGITVO]2.0.CO;2.

Ressel, M.W., Dendas, M., Lujan, R., Essman, J., and Shumway, P.J., 2015, Shallow expressions of Carlin-type hydrothermal systems: An example from the Emigrant Mine, Carlin trend, Nevada, in New Concepts and Discoveries: Geological Society of Nevada 2015 Symposium, p. 409-433.

Ressel, M.W., and Henry, C.D., 2006, Igneous geology of the Carlin trend, Nevada: Development of the Eocene plutonic complex and significance for Carlin-type gold 
deposits: Economic Geology, v. 101, p. 347-383, doi:10.2113/gsecongeo.101.2.347.

Sharp, R.P., 1939, The Miocene Humboldt Formation in Northeastern Nevada: The Journal of Geology, v. 47, p. 133-160, doi:10.1086/624749.

Sluijs, A., Zeebe, R.E., Bijl, P.K., and Bohaty, S.M., 2013, A middle Eocene carbon cycle conundrum: Nature Geoscience, v. 6, p. 429-434, doi:10.1038/ngeo1807.

Smith, M.E., Cassel, E.J., Jicha, B.R., Singer, B.S., and Canada, A.S., 2017, Hinterland drainage closure and lake formation in response to middle Eocene Farallon slab removal, Nevada, U.S.A.: Earth and Planetary Science Letters, v. 479, p. 156-169, doi:10.1016/j.eps1.2017.09.023.

Smith, J.F.J., and Ketner, K.B., 1976, Stratigraphy of post-Paleozoic rocks and summary of resources in the Carlin-Pinon Range area, Nevada: U.S. Geological Survey Professional Paper 867-B, p. 1-48.

Wallace, A.R., Perkins, M.E., and Fleck, R.J., 2008, Late Cenozoic paleogeographic evolution of northeastern Nevada: Evidence from the sedimentary basins: Geosphere, v. 4, p. 36-74, doi:10.1130/GES00114.1.

White, L.T., and Ireland, T.R., 2012, High-uranium matrix effect in zircon and its implications for SHRIMP U-Pb age determinations: Chemical Geology, v. 306-307, p. 78-91, doi:10.1016/j.chemgeo.2012.02.025.

Yeend, W.R., 1974, Gold-bearing gravels of the ancestral Yuba River, Sierra Nevada, California: U.S. Geological Survey Professional Paper 772. 